\title{
An alternative approach to modeling the country's business climate in conditions of limited information
}

\author{
Dmytro Ocheretin ${ }^{1,}$, Vita Los $^{1}$, Hanna Kucherova ${ }^{2}$, and Olha Bilska ${ }^{2}$ \\ ${ }^{1}$ Zaporizhzhia National University, Faculty of Economics, Zaporizhzhia, 69600, Ukraine \\ ${ }^{2}$ Classic Private University, Chair of Economics, Zaporizhzhia, 69002, Ukraine
}

\begin{abstract}
To date, the country's business climate characterizes the state of economic development and the results of its effectiveness. One of the key indicators that determine the business climate is the business confidence index (BCI). The paper proposes an approach to modeling the business climate of the country, which is based on the principles of information transparency, and makes it possible to assess the development trends of the studied indicator. The proposed approach is based on the taxonomy method, which allows one to identify the measure of influence of each factor included in the model and exclude the influence of the subjective assessment of the researcher. This approach has been tested on the example of Ukraine. The quarterly values of socio-economic indicators for the past twelve years (2008-2019) were taken as input data. Based on the correlation analysis, from the generated array of incoming data, only those indicators were selected that have a significant relationship with the business confidence index. It has been established that the GDP annual growth rate and retail sales have the greatest impact on the business confidence index. A forecast has been built for the trend of changes in the business confidence index (forecast accuracy of 87.55\%), which proves the similarity of development trends in the country's business climate. The results obtained make it possible to analyze the cyclical development of the country's economy with high accuracy and reliability.
\end{abstract}

\section{Introduction}

The formed business climate of the country at the same time acts as a result and a prerequisite for its development, as it sets limits on the development of social and economic processes and determines the results of their effectiveness. That is why leading researches do not abandon the search for new methods for assessing, forecasting and improving the country's business climate.

Since the essence of the "business climate" category is poorly structured, it is quite difficult to achieve clarity in the selection of key indicators, their boundaries, and a high level of validity in choosing modeling methods. In addition, the challenge is complicated by the fact that the level of information transparency of the sources necessary for modeling the business climate differs significantly at the level of countries and separate websites. Information transparency is defined as "a qualitative attribute of information, which a certain level extent of the achievement forms an additional spectrum of the properties of that part of information that was adequately perceived and subject to processing" [1]. In this context, in practice, questions arise regarding the insufficient level of openness, accessibility, reliability of information, the impossibility of comparing it, which generally determines the risk of insufficient information transparency of aspects whose coverage makes it possible to increase the accuracy and reliability in results of modeling the business climate.

However, for the time being a powerful methodological set of tools has been formed, the use of which makes it possible in one way or another to reflect the level of the country's business climate, its structure and prospects for changes in dynamics under the influence of external factors and internal disturbances in open socioeconomic systems. The assumptions that lie in the chosen methodology for assessing the business climate form a measure of error, the admissibility of which is also a separate issue of confidence in the modeling results.

Today, the key indicators that determine the business climate are the business confidence index (BCI) available from the Organisation for Economic Co-operation and Development (OECD) and the industry confidence index (ICI). The indicators are based on the principle of confidence and awareness of business entities both in relation to the current state of the country's economy and its changes. On the one hand, confidence is the result of the reliability of the estimated indicators that reflect the state of the economy and its long-term changes, and on the other, the consequence of the development of the economy. In this, the cyclical and interdependence of the laws of economic development is manifested, which also determine the quality of the country's formed business climate.

* Corresponding author: odvisua@gmail.com 
The business confidence index is based on the mean of the balances the evaluations of entrepreneurs considering factors such as production, orders, inventories, the current economic situation and expectations of business entities regarding change in the immediate future. The industry confidence index (ICI) also based on the results of surveys of directors of industrial companies depending on the size of the enterprise. This survey considers the following questions: current level of global demand, current inventory levels, current business situation, expected production, expected employment, and the expected business situation. The advantage of these indicators is their outstripping nature, since their publication occurs earlier than other key economic indicators. In addition, the close relationship of business confidence index with the country's GDP has already been proven, the volumes of which are published later [2].

In the research S. Feuerriegela and J. Gordon [3] the business confidence index is one of the main indicator in the semantic path modeling of German economic climate. However, the weak point of indicators remains the methodology for their assessment, including the survey. This method is not without significant risks of use, including in terms of the variability of the opinions of respondents, the lack of awareness in the whole spectrum of economic issues, and so on. In addition, the use of this method of researching the business climate is quite painstaking, lengthy and costly work. Therefore, it makes sense to justify an alternative approach to assessing the country's business climate in order to maintain its leading character and simplify the receipt of assessment results.

In this direction, researchers such as Helder Ferreirade Mendonça and André Filipe Guedes Almeida [4] made successful attempts, who, as a result of studies, proved the weighty significant the impact of the credibility of monetary policy on business confidence.

Noteworthy are the many constructed business confidence indices based on the short-term memory (BiLSTM) model [5], the informative weight of which lies in the identified opportunities for analyzing interindustry relations. The construction of artificial neural networks was successfully used to predict the business confidence index in papers $[2,6]$ under the influence of changes in industrial producer prices, unemployment rate, GDP annual growth rate, consumer spending, new orders, inventories, exports, imports, industrial production and steel production. Thus, the methodology for modeling the business climate of countries is expanding through the use of not only subjective, but also objective research methods with a significantly higher level of accuracy of the results. Continuing the research trend, athors offer an alternative approach to modeling the business climate.

\section{Methodical approach to modelling}

The approach proposed by the authors to modeling the country's business climate (Figure 1) is based on the principles of information transparency and consists of five interrelated stages.

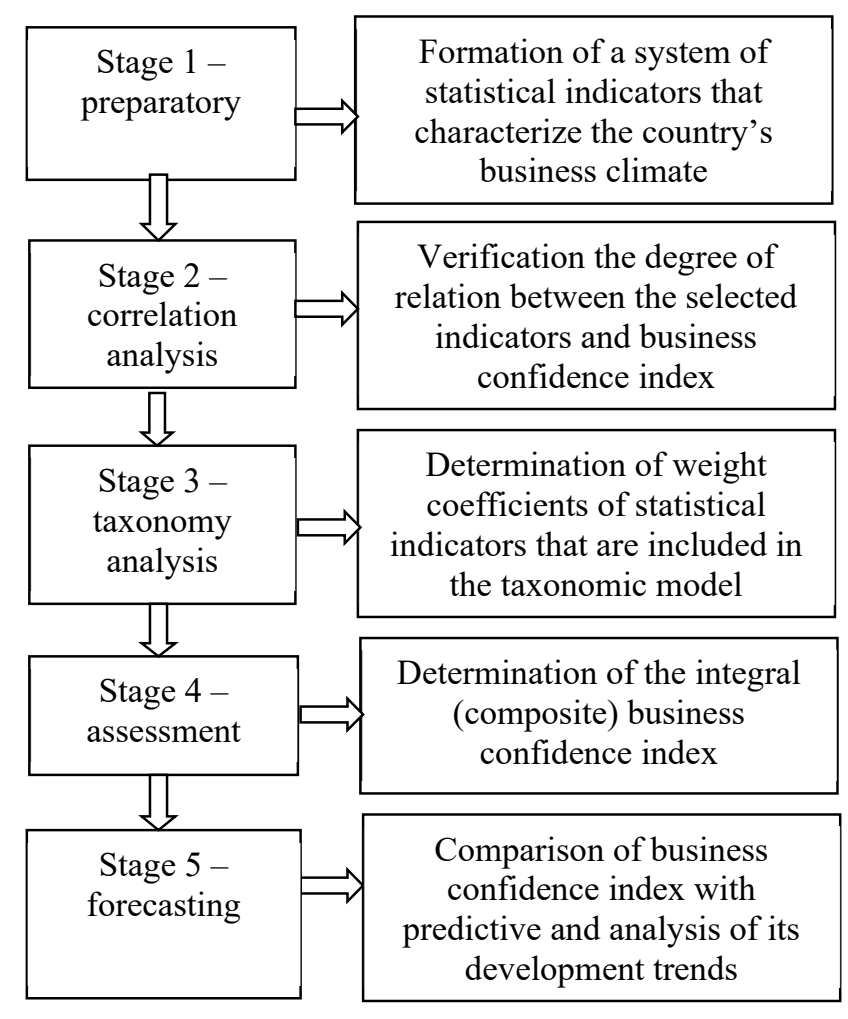

Fig. 1. Stages of modeling the country's business climate in the conditions of information transparency.

At the first stage of the proposed approach, the socioeconomic indicators that characterize the country's business climate are analyzed. Based on the analysis, an information base of statistical indicators is formed. To fill the information base, official statistics of the National Bank of Ukraine [7] and the international data site "Trading Economics" [8-18] were used. The research used quarterly statistics for the period from the first quarter of 2008 to the third quarter of 2019.

At the second stage, a correlation analysis is carried out between the selected statistical indicators and the business confidence index. For further analysis, only those indicators are selected that have a correlation coefficient with the business confidence index greater than 0,7 .

The third stage involves the determination of weights. To determine them, the taxonomic method is used. The essence of the method is to calculate the distance between indicators that are included in the model and included in the structure of the integral indicator. The distance between the indicators of the taxonomic model is determined using the formula [19]:

$$
a_{r s}=\frac{1}{m} \sum_{i=1}^{m}\left|b_{i r}-b_{i s}\right|, r, s=\overline{1, n}
$$

where $a_{r s}-$ the distance between the indicators $r$ and $s$; $b_{r}, b_{s}$ - standardized values indicators $r$ and $s$;

$m$ - number of observations; $n$ - number of indicators.

Matrix $A$, which displays the distances between the studied indicators, has the form: 


$$
A=\left[\begin{array}{cccc}
0 & a_{12} & \ldots & a_{1 n} \\
a_{21} & 0 & \ldots & a_{2 n} \\
\ldots & \ldots & 0 & \ldots \\
a_{n 1} & \ldots & \ldots & 0
\end{array}\right]
$$

After determining the distances between the studied indicators, a critical distance is calculated that characterizes the maximum distance between two indicators:

$$
a_{\text {crit }}=\max _{r} \min _{s} a_{r s}
$$

Next, for each indicator, the sum of all distances that do not exceed the critical distance is found:

$$
p_{j}=\sum_{s=1}^{m} a_{j s} \text { for } a_{j s} \leq a_{c r i t}
$$

Based on the data obtained, as a result of the calculations, weight coefficients are determined by the formula:

$$
w_{j}=\frac{p_{j}}{\sum_{j=1}^{n} p_{j}}
$$

Thus, using the taxonomic method, the values of weight coefficients of each component of the integral indicator of the country's business climate level are calculated.

The fourth stage of the proposed approach provides for an integrated assessment of the level of the country's business climate. In a formulaic form, the calculation of the composite index of business activity in a region is as follows [20]:

$$
\overline{B C I}_{i}=\sum_{i=1}^{n} I_{i} \cdot w_{i}
$$

where $\overline{B C I}_{i}$ - the composite index of business activity value in the quarter $i$;

$I_{i}$ - value of indicators, which characterizes the business climate in the quarter $i$;

$i$ - the period;

$w_{i}$ - weight coefficient of the corresponding indicator.

As a result of the calculations, obtains the time series of the business confidence index of enterprises for all analyzed time periods.

At the last stage, a comparison is made of the trends of the predicted value of the business confidence index and real. Based on the predicted value obtained, a conclusion is drawn on the future direction of the country's business climate.

The proposed approach to modeling the country's business climate makes it possible to identify the degree of influence of individual socio-economic indicators on the development path of business expectations of enterprises and to analyze the cyclical nature of the country's economy.

\section{Construction and forecast of business confidence index}

Approbation of the proposed approach regarding modeling the country's business climate in the conditions of information transparency was carried out on the example of Ukraine. At the first stage of modeling, the formation of an information database of input data set was carried out. It should be noted that during the formation of an array of input data, it is necessary to take into account the nature (specificity) of the country's economic development. It is also important that in a real situation, some socio-economic indicators can be interchanged, supplemented, excluded depending on the economic policy of the country. Equally important is the informational transparency of statistical information on the necessary socio-economic indicators. Considering all these aspects and the experience of domestic and foreign researchers, the authors made the assumption that the development of the country's business climate (which is characterized by the business confidence index (BCI)) is affected by a number of socio-economic indicators, such as: money supply M1, M2, M3, unemployment rate, GDP annual growth rate, consumer spending, retail sales, exports, imports, industrial production and steel production affect the development of the country's business climate, which is characterized by the business confidence index (BCI), Unemployment Rate, GDP Annual Growth Rate, Consumer Spending, Retail Sales, Exports, Imports, Industrial Production and Steel Production [8-18]. Accordingly, an information database of input statistical data for the past twelve years (20082019) was formed. The input data in the system of statistical indicators are given in the corresponding units of measurement; therefore, to be able to compare the data, normalization with an average value of 100 was carried out.

The second stage of modeling is to check the degree of relation between the studied indicators. Based on the results of the correlation analysis, a correlation matrix was obtained that characterizes the relationship between the input set of socio-economic indicators and the business confidence index (Table 1).

Table 1. Correlation between socio-economic indicators and the business confidence index of Ukrainian enterprises.

\begin{tabular}{|l|c|}
\hline Economic indicators & Value of correlation \\
\hline Money supply M1 & $-0,01$ \\
\hline Money supply M2 & $-0,07$ \\
\hline Money supply M3 & $-0,07$ \\
\hline Unemployment rate & $-0,44$ \\
\hline GDP annual growth rate & 0,86 \\
\hline Consumer spending & 0,13 \\
\hline Retail sales & 0,80 \\
\hline Exports & 0,77 \\
\hline Imports & 0,70 \\
\hline Industrial production & 0,71 \\
\hline Steel production & 0,72 \\
\hline
\end{tabular}

Based on this matrix, we can conclude that there is a close relationship between GDP annual growth rate, retail sales, export, import, industrial production and steel production and the business confidence index of Ukrainian enterprises.

Thus, of the eleven selected socio-economic indicators, six will be included in the taxonomic model. 
These indicators make up the set of socio-economic indicators that affect the country's business climate.

The next stage of modeling is the calculation of weight coefficients. According to formula (1) the distance between the indicators that are included in the taxonomic model is calculated. The distance calculation results are given in Table 2.

Table 2. Matrix of distances $A$.

\begin{tabular}{|c|c|c|c|c|c|c|}
\hline $\begin{array}{c}\text { Economic } \\
\text { indicators }\end{array}$ & $\begin{array}{c}\text { Retail } \\
\text { sales }\end{array}$ & $\begin{array}{c}\text { Indus- } \\
\text { trial } \\
\text { produc- } \\
\text { tion }\end{array}$ & $\begin{array}{c}\text { Steel } \\
\text { pro- } \\
\text { ducti- } \\
\text { on }\end{array}$ & $\begin{array}{c}\text { Ex- } \\
\text { port }\end{array}$ & $\begin{array}{c}\text { Im- } \\
\text { port }\end{array}$ & $\begin{array}{c}\text { GDP an- } \\
\text { nual } \\
\text { growth } \\
\text { rate }\end{array}$ \\
\hline $\begin{array}{c}\text { Retail sa- } \\
\text { les }\end{array}$ & 0 & 8,91 & 14,37 & 14,91 & 15,55 & 7,52 \\
\hline $\begin{array}{c}\text { Industrial } \\
\text { production }\end{array}$ & 8,91 & 0 & 10,81 & 13,09 & 14,16 & 4,39 \\
\hline $\begin{array}{c}\text { Steel pro- } \\
\text { duction }\end{array}$ & 14,37 & 10,81 & 0 & 13,68 & 15,44 & 9,63 \\
\hline Export & 14,91 & 13,09 & 13,68 & 0 & 7,27 & 11,99 \\
\hline Import & 15,55 & 14,16 & 15,44 & 7,27 & 0 & 13,24 \\
\hline $\begin{array}{c}\text { GDP an- } \\
\text { nual } \\
\text { growth ra- } \\
\text { te }\end{array}$ & 7,52 & 4,39 & 9,63 & 11,99 & 13,24 & 0 \\
\hline
\end{tabular}

Table 2 shows that the minimum distance is present between industrial production and GDP annual growth rate. Also, a small distance is observed between export and import, GDP annual growth rate and retail sales.

After determining the distances between the studied indicators, a critical distance is calculated that characterizes the maximum distance between two indicators in accordance with formula (2). It is equal $a_{\text {crit }}=9,63$.

By the formula (3), the sum of all distances that do not exceed the critical one is calculated for all indicators. The calculation results are shown in Table 3.

Table 3. Value of coefficient $p_{j}$.

\begin{tabular}{|l|c|}
\hline \multicolumn{1}{|c|}{ Economic indicators } & Coefficient, $\boldsymbol{p}_{\boldsymbol{j}}$ \\
\hline Retail sales (RS) & 16,43 \\
\hline Industrial production (IP) & 13,30 \\
\hline Steel production (SP) & 9,63 \\
\hline Exports & 7,27 \\
\hline Imports & 7,27 \\
\hline GDP annual growth rate (GDP_AGR) & 21,53 \\
\hline
\end{tabular}

In accordance with the above methodology, the next step is to calculate the weighting coefficients. By the formula (4), the set of weight coefficients was obtained, which is shown in Table 4.

Table 4. The set of weight coefficient $w_{i}$.

\begin{tabular}{|l|c|}
\hline \multicolumn{1}{|c|}{ Economic indicators } & Weight coefficient, $\boldsymbol{w}_{\boldsymbol{i}}$ \\
\hline Retail sales (RS) & 0,218 \\
\hline Industrial production (IP) & 0,176 \\
\hline Steel production (SP) & 0,128 \\
\hline Export & 0,096 \\
\hline Import & 0,096 \\
\hline GDP annual growth rate (GDP_AGR) & 0,286 \\
\hline
\end{tabular}

Analyzing the data in Table 4, it is clear that the GDP annual growth rate $(0,286)$ turned out to be the most significant factor, so we can say that it has the greatest impact on the business confidence index of Ukrainian enterprises. The volume of exports and imports have the least impact on the level of the business climate of the country and is only 0,096. Weighted socio-economic indicators are integral components of the composite business confidence index.

The fourth stage of modeling is the calculation of the composite index of business activity, that is, the business confidence index, which determines the level of the business climate of the studied country as a whole. Using the obtained values of weighting coefficients and normalized socio-economic indicators, the forecast value of the composite index of business activity is obtained as follows:

$$
\begin{aligned}
& \overline{B C I}_{i}=W_{1} \cdot R S_{i}+W_{2} \cdot I P_{i}+W_{3} \cdot S P_{i}+W_{4} \times \\
& \times \text { Exports }_{i}+W_{5} \cdot \operatorname{Imp} \text { orts } \\
& +W_{6} \times \\
& \times G D P_{-} A G R_{i}=0,218 \cdot R S_{i}+0,176 \times \\
& \times I P_{i}+0,128 \cdot S P_{i}+0,096 \cdot \text { Exports }_{i}+ \\
& +0,096 \cdot \text { Imports }_{i}+0,286 \cdot G D P_{-} A G R_{i}
\end{aligned}
$$

The dynamics of the business confidence index and the composite index of business activity obtained by the taxonomic method for Ukrainian enterprises are shown in Figure 2. The average absolute error in predicting the composite index of business activity (MAPE) is $12,45 \%$.

According to Figure 2, authors note that the actual level of the business confidence index differs from the calculated composite index by an average of $9.65 \%$, which is acceptable and does not reduce the accuracy and information content of the calculated index. The trends of the studied indicators are characterized by a high level of volatility, in particular during the crisis period for the country (2008-2009, 2014-2015), during the intermediate period of stabilization between them, the fluctuation trends decrease, but the volatility of the trends is significant.

For the research period, there are two local minimums according to the fact and calculated indicators, the first was recorded in the first quarter of 2009 - 72 (business confidence index) and 81,11 (composite index), the second in the first quarter of 2015 with 83,5 (business confidence index) and 80,96 (composite index). The indicated local minimum generate a trend support line for the period under research, a position below which signals a deterioration in the situation and the formation of a new downtrend. Studying the local maximum of the indicator trends, authors note that for the period under review, the trends were corrected; therefore, three local maximum can be distinguished. The first maximum at the beginning of the research period in the first quarters of 2008 with values of 140,1 (business confidence index) and 113,35 (composite index). The second local maximum was recorded in the first quarter of 2011 with values of 123,2 (business confidence index), however, the composite index was outstripping, so its local maximum with a value of 110,91 was recorded a quarter earlier in the fourth 
quarter of 2010. The third local maximum was recorded in the first quarter 2018 with a value of 120,6 (business confidence index), however, the composite index again outstripped the trend of the actual indicator and its local maximum was recorded a quarter earlier in the fourth quarter of 2017 with a value of 105,8. In general, local maximums of the trends of the studied indicators form a resistance line, the violation of which gives grounds to assert the formation of a new upward trend.

According to the forecast data of the composite index, the index is forecasted to be at the level of 100,81 for the first quarter of 2019 , which is $97,19 \%$ of the same indicator in the fourth quarter of 2018, the index value is forecasted at 104,023 for the second quarter of 2019, and 103,91 for the third quarter of 2019. The average value of the composite index according to 2019 is $87,5 \%$ of the actual business confidence index value.

In general, a range is visualized in which the trends of the studied indicators fluctuate, which determines the basic level of the country's business climate, limited to
90-120 points. Violation of this range is possible through the formation of a new upward trend due to the implementation of qualitative changes in the directions of development of investment platforms, park mechanisms, activation of internal processes of self-organization and hidden resource potential in the country, in the conditions of state support for the development of technology transfer, protection of investors' interests, control of corruption and other.

In addition, the most important thing is that the tendency of the studied indicators is identical, in particular, during the period of the emergence of crisis phenomena (beginning of 2009, end of 2014 and beginning of 2015), the decrease in the level of indicators is similar, which suggests that there is a real possibility of using the alternative to business confidence index, which calculated by the taxonomic method of in order to predict the business climate in conditions of limited information transparency.

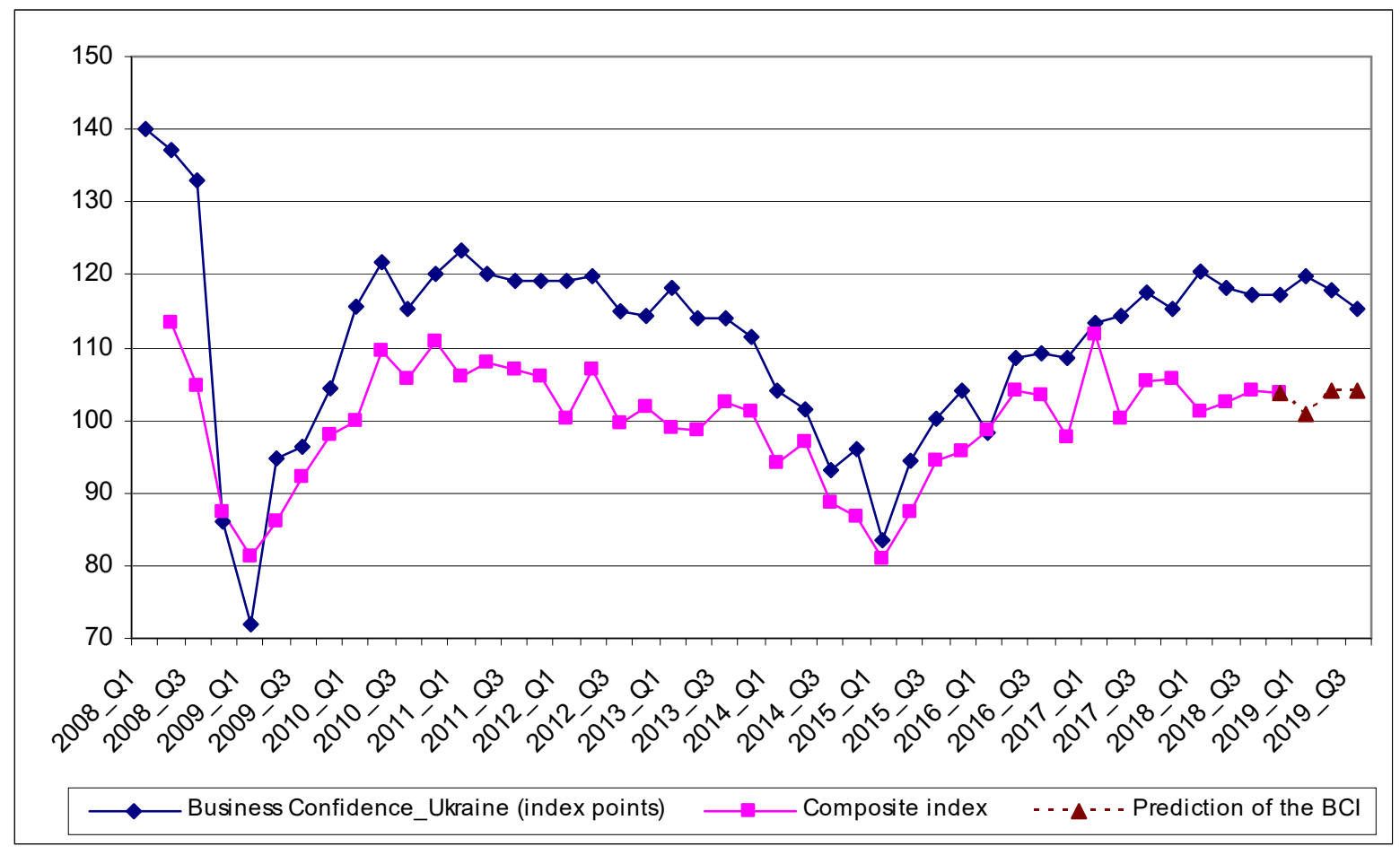

Fig. 2. The dynamics of the business confidence index and the composite index of business activity.

\section{Conclusions}

Using a reasonable alternative approach to modeling the country's business climate has proved the possibility of implementing a simplified procedure for assessing the trends of its changes using the composite index of business activity calculated by the authors. The methodology of the study consists in substantiating the use of the taxonomy method for calculating this index and studying the identity of its dynamics to changes in the generally accepted business confidence index. An analysis of the trends of the calculated composite and actual indices of business confidence proved the similarity of trends, including during the formation of local maximums and minimums.

A variable component in the proposed alternative approach is a combination of key statistical indicators. The set of statistical indicators that is justified during the research, which determines the business climate, is basic for the countries that are developing. Whereas for developed countries, the set of key indicators is desirable to review in accordance with the characteristics of the development of their economies. The problem for the implementation of an alternative approach remains limited access to key statistics, which is the result of a policy of ensuring information transparency in different countries. 
The prospect of a reasonable approach is that in the case of ensuring the necessary level of information transparency of input data, there is a real opportunity by statistical methods to ensure the identity of the index trends: the business confidence index and the composite index of the business activity proposed by the authors.

The effectiveness of the proposed alternative approach is manifested in saving costs for generating input data for assessing the country's business climate by using official statistics instead of survey results, the subjectivity of which is much higher. In general, the implemented alternative approach is unified, can serve as the basis for further deepening the methodological provisions for studying the business climate of countries with high accuracy and reliability of the results.

\section{References}

1. H. Kucherova, A. Didenko, O. Kravets, Advances in Economics, Business and Management Research 99, 201-205 (2019), doi:10.2991/mdsmes-19.2019.38

2. V. Los, D. Ocheretin, H. Kucherova, O. Bilska, Advances in Economics, Business and Management Research 95, 320-324 (2019), doi:10.2991/smtesm19.2019.62

3. S. Feuerriegela, J. Gordon, Eur J Oper Res 272, $162-$ 175 (2019), doi:10.1016/j.ejor.2018.05.068

4. H.F. de Mendonca, A.F.G. Almeida, Empir Econ (2018), doi:10.1007/s00181-018-1533-5

5. H. Sakaji, R. Kuramoto, H. Matsushima, K. Izumi, T. Shimada, K. Sunakawa, in Proceedings of the First Workshop on Financial Technology and Natural Language Processing (FinNLP@IJCAI 2019), Macao, China, August 12, 2019, pp. 40-46

6. S. Arslankaya, V. Öz, Sakarya University Journal of Science 22, 1482-1492 (2018), doi:10.16984/saufenbilder.456518

7. National bank of Ukraine, Business expectations of enterprises (2019),

https://bank.gov.ua/control/uk/publish/category?cat_ $\mathrm{id}=58374$. Accessed 21 Mar 2020

8. Tradingeconomics.com, Ukraine Money Supply M1 (2019), https://tradingeconomics.com/ukraine/moneysupply-m1. Accessed 21 Mar 2020

9. Tradingeconomics.com, Ukraine Money Supply M2 (2019), https://radingeconomics.com/ukraine/moneysupply-m2. Accessed 21 Mar 2020

10. Tradingeconomics.com, Ukraine Money Supply M3 (2019), https://tradingeconomics.com/ukraine/moneysupply-m3. Accessed 21 Mar 2020

11. Tradingeconomics.com, Ukraine Unemployment Rate (2019), https://tradingeconomics.com/ukraine/unemploymen t-rate. Accessed 21 Mar 2020
12. Tradingeconomics.com, Ukraine GDP Annual Groth Rate (2019) https://tradingeconomics.com/ukraine/gdp-growthannual. Accessed 21 Mar 2020

13. Tradingeconomics.com, Ukraine GDP Consumer Spending (2019), https://tradingeconomics.com/ukraine/consumerspending. Accessed 21 Mar 2020

14. Tradingeconomics.com, Ukraine Retail Sales YoY (2019), https://tradingeconomics.com/ukraine/retailsales-yoy. Accessed 21 Mar 2020

15. Tradingeconomics.com, Ukraine Exports (2019), https://tradingeconomics.com/ukraine/exports. Accessed 21 Mar 2020

16. Tradingeconomics.com, Ukraine Imports (2019), https://tradingeconomics.com/ukraine/imports. Accessed 21 Mar 2020

17. Tradingeconomics.com, Ukraine Industrial Production (2019), https://tradingeconomics.com/ukraine/industrialproduction. Accessed 21 Mar 2020

18. Tradingeconomics.com, Ukraine Steel Production (2019), https://tradingeconomics.com/ukraine/steelproduction. Accessed 21 Mar 2020

19. L.A. El'shin, Regional Economics: Theory and Practice 15, 1540-1551 (2017)

20. M.R. Safiullin, L.A. El'shin, A.I. Shakirova, Vestnik Rossiiskoi akademii nauk 82, 623-627 (2012) 